\title{
Effect of Phosphorus, VAM and FYM on Soil Fertility Status under Rice Cultivation
}

\author{
Abhishek Kumar Shukla ${ }^{1 *}$, Sanjay shahi ${ }^{2}$, Niteesh Patel ${ }^{1}$ and Sandeep Patel ${ }^{1}$ \\ ${ }^{1}$ Udai Pratap Autonomous College, Varanasi (U.P.), India \\ ${ }^{2}$ Deptt of Agricultural Chemistry and Soil Science, Udai Pratap Autonomous College, \\ Varanasi (U.P.), India \\ *Corresponding author
}

\section{A B S T R A C T}

\begin{tabular}{|l|}
\hline Ke y w o r d s \\
VAM, FYM, \\
Rice, SSP and Soil \\
\hline Article Info \\
\hline $\begin{array}{l}\text { Accepted: } \\
\text { 22 June 2020 } \\
\text { Available Online: } \\
\text { 10 July 2020 }\end{array}$ \\
\hline
\end{tabular}

A field experiment was conducted during Kharif season 2018-2019 on research plot of Udai Pratap Autonomous College, Varanasi (U.P.) adjoining the Department of Agricultural Chemistry and Soil Science, The experiment was conducted with seven treatments were control $\left(\mathrm{T}_{1}\right), 60 \mathrm{~kg} \mathrm{P}^{-1}\left(\mathrm{~T}_{2}\right) 60 \mathrm{~kg} \mathrm{P} \mathrm{ha}^{-1}+\mathrm{VAM}\left(\mathrm{T}_{3}\right), 30 \mathrm{~kg} \mathrm{P} \mathrm{pa}^{-1}\left(\mathrm{~T}_{4}\right)$, $30 \mathrm{~kg} \mathrm{Pha}{ }^{-1}+$ VAM $\left(\mathrm{T}_{5}\right), 30 \mathrm{~kg} \mathrm{Pha}^{-1}+\mathrm{VAM}+10 \mathrm{tha}^{-1} \mathrm{FYM}\left(\mathrm{T}_{6}\right), 80 \mathrm{~kg} \mathrm{P} \mathrm{ha}^{-1}\left(\mathrm{~T}_{7}\right)$, the rice crop was laid out in randomized block design (RBD) with four replication . Soil pH and EC was significantly decreased with addition of phosphorus, VAM and FYM. Higher soil Organic carbon content was observed with the application of $30 \mathrm{~kg} \mathrm{P} \mathrm{ha}^{-1}+\mathrm{VAM}+$ FYM 10 ta $/$ ha $\left(\mathrm{T}_{6}\right)$. The plots treated with $30 \mathrm{~kg} \mathrm{P} \mathrm{ha}^{-1}+\mathrm{VAM}+\mathrm{FYM} @ 10 \mathrm{ta} \mathrm{ha}^{-1}\left(\mathrm{~T}_{6}\right)$ recorded significantly higher available nitrogen content as compared to other treatments. The effect of various treatment of phosphorus fertilizer, VAM and FYM on available phosphorus content of soil was recorded significantly higher in the treatment $T_{3}$ i.e. $60 \mathrm{~kg}$ $\mathrm{P} \mathrm{ha}^{-1}+$ VAM. Significantly higher soil available potassium content was observed in the treatment $30 \mathrm{~kg} \mathrm{P} \mathrm{ha}{ }^{-1}+$ VAM + FYM @ 10ta ha ${ }^{-1}\left(\mathrm{~T}_{6}\right)$. Application 30 kg P ha ${ }^{-1}+\mathrm{VAM}+$ FYM 10 ta ha ${ }^{-1}$ i.e $\left(\mathrm{T}_{6}\right)$ were recorded significant higher dry matter, straw yield and grain yield of rice crop.

\section{Introduction}

Rice (Oryza sativa L.) is the most common and important food crop of India in terms of both the area and production. It has the second highest wide production after maize. Rice production in India crossed the mark of 112 million tonnes achieved in 2017-18 accounting for $21.19 \%$ of global production in the year. The productivity of rice has $3742 \mathrm{~kg}$ per hectare in 2017-18. India has largest area
(43.20 million hectare) followed by China (30.35 m ha), Indonesia (12.16), Bangladesh (12.0 $\mathrm{m} \mathrm{ha})$ and Vietnam (7.66 m ha) (FAO STAT 2017). The major rice producing states in India falls in the regions of the middle and lower Ganga plains and the coastal lowlands of the peninsular India. Rice is grown in almost all the states of India but its cultivation is mainly concentrated in river valleys, deltas and low lying coastal areas in India. Andhra Pradesh (2.16 m ha), Bihar (3.21 m ha), 
Madhya Pradesh (2.02 m ha), West Bengal (5.46 $\mathrm{m} \mathrm{ha}$ ) and Uttar Pradesh (5.87 m ha) lead in the area. West Bengal (15.75MT), Uttar Pradesh (12.51 MT) and Punjab (11.82 MT) have the highest share in rice production.

Phosphorus is an essential element classified as primary and also known as "Life of plant". Plant required adequate $\mathrm{P}$ from the very early stages of growth for optimum crop production (Grant et al., 2001). Phosphorus is one of the major nutrients generally added to soil in form of fertilizer. One of the main roll of the phosphorus is plant is in transfer of energy ATP and also involved in root development and in metabolic activities especially in synthesis of protein (D. Rodriguez, 2002). Phosphorus is major growth-limiting nutrient and unlike the case for nitrogen, there is no large atmospheric source that can be made biologically available (Laxminarayana 2005). The phosphorus concentration in soil usually ranges from 100 to $2000 \mathrm{mg} \mathrm{P} \mathrm{kg}^{-1}$ soil representing approximately 350 to $7000 \mathrm{mg} \mathrm{P}$ $\mathrm{kg}^{-1}$ in the surface $25 \mathrm{~cm}$ of the soil, although only a small proton of this $\mathrm{P}$ is immediately available for crop uptake (Lanerd 2005). Phosphorus in soil solution is found lower range from $0.001 \mathrm{mg} / \mathrm{L}$. In general plant root absorbs phosphorus in form of orthophosphate ions $\left(\mathrm{H}_{2} \mathrm{PO}_{4}{ }^{-2}\right.$ and $\left.\mathrm{HPO}_{4}{ }^{-2}\right)$ are primary forms of phosphorus taken up by plant. Phosphorus moves to the root surface through diffusion (Chaturvedi 2006).The phosphorus content of soil is quit variable ranging from less than $0.04 \% \mathrm{P}_{2} \mathrm{O}_{5}$ in sandy soil to $0.3 \%$ in highly organic matter soil. Soil phosphorus levels are affected by erosion, crop removal and phosphorus fixation. The soil low in organic matter may contain only $3 \%$ of their total phosphorus in organic form, but highly organic matter may contain $50 \%$ or more of their total phosphorus in organic form (Bray and Kurtz 1945). The available phosphorus in Indian soil $52.5 \%$ of districts are in low phosphorus category $46 \%$ are medium phosphorus category and only $1.6 \%$ is high phosphorus category. Plant required phosphorus for their energy transfer reaction, development of reproductive system, crop maturity, root growth and protein synthesis.

The term Mycorrhiza used to describe the symbiotic association between a fungus and a root of higher plant (Frank, 1885). Both of the host plant and fungal member, benefited potentially form this association (Powel and Bagyarj, 1984). There are almost seven types of mycorrhizal (Reeves and Renente, 1991). Near about $80 \%$ of all terrestrial plant species form endomycorrhiza. ie vesicular arbuscular mycorrhizal (VAM). Arbuscular mycorrhizal fungi that specifically colonize roots of a plant species are therefore likely to be great relevance of fuction and their identification is important to understand the ecology of plant fungus interaction in natural ecosystem (Hegalson et al, 2002) vesicular arbuscular mycorrhizal fungi are ubiquitous in their distribution and occur abundantly. Majority of lowering plants have the dynamic association of VAM fungi.

\section{Materials and Methods}

The present investigation entitled in the effect of phosphorus fertilization on its transformation under rice crop (Oryza sativa L"). The field experiment was conducted during Kharif season 2018-2019 on research plot of Udai Pratap Autonomous College, Varanasi (U.P.) adjoining the Department of Agricultural Chemistry and Soil Science. The initial physico-chemical properties of soil have been presented in table 1.Varanasi is found under sub-tropical climate and situated in eastern U.P. whereas the precipitation is normally spread over period of three and four months i.e. started from the last week of June to the second week of October in rainy season. The distribution of average annual rain fall is $96.65 \mathrm{~cm}$. 
The experiment was conducted with seven treatment were control $\left(\mathrm{T}_{1}\right), 60 \mathrm{~kg} \mathrm{P} \mathrm{ha}^{-1}\left(\mathrm{~T}_{2}\right)$ $60 \mathrm{~kg} \mathrm{P} \mathrm{ha}{ }^{-1}+\operatorname{VAM}\left(\mathrm{T}_{3}\right), 30 \mathrm{~kg} \mathrm{P} \mathrm{Pa}^{-1}\left(\mathrm{~T}_{4}\right)$, $30 \mathrm{~kg} \mathrm{P} \mathrm{ha}^{-1}+\mathrm{VAM}\left(\mathrm{T}_{5}\right), 30 \mathrm{~kg} \mathrm{Pha}^{-1}+\mathrm{VAM}$ $+10 \mathrm{tha}^{-1} \mathrm{FYM}\left(\mathrm{T}_{6}\right), 80 \mathrm{~kg} \mathrm{P} \mathrm{ha}^{-1}\left(\mathrm{~T}_{7}\right)$, the rice crop was laid out in randomized block design (RBD) with four replication.

All grass has been removed from the plot and plots and soil sample have been taken from each plot at 30 DAS and at harvesting. Khurpi and auger have been used as sampling tools. Sample was collected in plastic bag. Soil samples were brought to the laboratory, air dried soil samples were crushed and pass through $2 \mathrm{~mm}$ round here sieve. The sieved samples were stored in the labeled polythene bag plot wise for conducting selected laboratory analysis.

A soil water suspension was prepared in ratio of 1: 2.5 and $\mathrm{pH}$ was recorded with the help of glass electrode digital $\mathrm{pH}$ meter (Jackson 1967). Electrical conductivity of soil sample was measured in 1:2.5 soil and water suspension at $25{ }^{0} \mathrm{C}$ temperature by $\mathrm{EC}$ Bridge (Bower and Wilcox, 1965). Organic carbon was determined by Walkley and Black's rapid titration method (Walkley and Black, 1934) as described by (Jackson 1967). The available nitrogen was determined by alkaline permanganate method (Subbiah and Asija, 1956). The available phosphorus in soil was determined by the Olsen's method (Olsen' et al., 1954). The available potassium was determined by neutral normal ammonium acetate method (Honway and Heidel, 1952).

The data collected from field and laboratory was analyzed statically by using standard procedure of randomized block design (RBD), (Cochram and Cox, 1959). Critical difference (C.D.) and standard error of mean (S.E.M.) were calculated to determine the significance among all the treatment mean.

\section{Results and Discussion}

This experiment was conducted to investigate the different dose of phosphorus in combination with or without FYM and VAM on growth and yield and under rice. The result of experiment recorded during availability of nutrient this investigation are presented and critically discussed in this chapter under following heads.

\section{Effect of phosphorus, FYM and VAM on soil fertility status}

\section{Soil Reaction (soil pH)}

The results pertaining to the influence of phosphorus, VAM and FYM application on soil $\mathrm{pH}$ measured at $30 \mathrm{DAS}$ and at harvesting stage under rice have been presented in figure -1 . Form the data it is evident that, the $\mathrm{pH}$ of soil increased continuously with days after transplanting under all treatments. The effect of various treatment on soil $\mathrm{pH}$ could be arranged in the order $T_{1}>T_{7}>T_{2}>T_{4}>T_{3}>$ $\mathrm{T}_{5}>\mathrm{T}_{6}$ and the values observed as 7.7, 7.6, $7.5,7.43,7.40,7.35$ to 7.7 at 30 DAT and 8.2, $8.0,7.8,7.68,7.58,7.52,7.49$ at harvesting under respective treatment. The significantly lower soil PH was recorded with addition of phosphorus, VAM and FYM. These result are corroborating with the findings of Sharma $e t$ al., (2007) and Sharma et al., (2013).

\section{Electrical conductivity (EC)}

The data related to the effect of phosphorus, VAM and FYM application on electrical conductivity of soil under rice, it showed they electrical conductivity increased continuously with advancement in crop growth stage under all treatments. The application of FYM with phosphorus + VAM recorder significantly lower electrical conductivity as compared to other treatments at all growth stages. The effect of different treatments on EC of soil 
was found in the order $T_{1}>T_{7}>T_{2}>T_{4}>T_{3}>$ $\mathrm{T}_{5}>\mathrm{T}_{6}$ and the values observed as $0.65,0.6$, $0.56,0.53,0.510 .49,0.46 \mathrm{~d} \mathrm{~S} \mathrm{~m}^{-1}$ at 30DAT and $0.73,0.69,0.64,0.620 .58,0.52 \mathrm{dS} \mathrm{m}^{-1}$ at harvesting. Further, the soil EC also decreased significantly with the application of FYM might be due to release of acids during decomposition of FYM which reduced the salt content responsible for exchange phenomenon.

\section{Organic carbon}

The result related to soil organic carbon content influence of phosphorus fertilization on its transformation under rice crop measured at $30 \mathrm{DAT}$ and at harvesting stage have been presented in table-2. Data shows that organic carbon continuously decreased with advancement of crop age under all treatments. Significantly higher soil Organic carbon content was observed with the application of $30 \mathrm{~kg} \mathrm{P} \mathrm{ha}^{-1}+\mathrm{VAM}+\mathrm{FYM} 10$ ta $/$ ha $\left(\mathrm{T}_{6}\right)$ in comparison to other treatments. The effect of different treatment on organic carbon content of soil was found in order of $\mathrm{T}_{6}>\mathrm{T}_{3}>\mathrm{T}_{5}>\mathrm{T}_{7}>\mathrm{T}_{2}>\mathrm{T}_{4}>\mathrm{T}_{1}$, and the values were $0.61,0.57,0.55,0.54,0.52,0.49,0.43 \%$ at 30DAT and $0.53,0.49,0.46,0.45,0.43$, 0.40 and $0.35 \%$ at harvesting stage under respective treatments. Maximum soil organic carbon content $\operatorname{inT}_{6}\left(30 \mathrm{~kg} \mathrm{P} \mathrm{ha}^{-1}+\mathrm{VAM}+\right.$ FYM 10ta $\mathrm{ha}^{-1}$ ) might be attributed to the direct incorporation of organic material through FYM and better root growth in influenced of VAM. The addition of FYM might have created environment conducive for formation of humic acid, which ultimately resulted in an increase in organic carbon content of soil (Bajpai et al., 2006). The result is corroborated with the findings of Prakash et al (2002) and Dadhich et al., (2011).

Table.1 Initial physio-chemical properties of experimental soil

\begin{tabular}{|r|l|c|}
\hline SN & \multicolumn{1}{|c|}{ Parameters } & Contents \\
\hline 1. & $\mathrm{pH}$ & 7.71 \\
\hline 2. & Electrical Conductivity $\left(\mathrm{dSm}^{-1}\right)$ & 0.61 \\
\hline 3. & Bulk density $\left(\mathrm{M} \mathrm{gm}^{-1}\right)$ & 1.35 \\
\hline 4. & Organic carbon $(\%)$ & 0.43 \\
\hline 5. & Available nitrogen $\left(\mathrm{kg} \mathrm{ha}^{-1}\right)$ & 210 \\
\hline 6. & Available phosphorous $\left(\mathrm{kg} \mathrm{ha}^{-1}\right)$ & 10.34 \\
\hline 7. & Available potassium $\left(\mathrm{kg} \mathrm{ha}^{-1}\right)$ & 220 \\
\hline
\end{tabular}

Table.2 Effect of phosphorus, FYM and VAM on organic carbon under rice crop

\begin{tabular}{|r|c|c|}
\hline \multirow{2}{*}{ Treatment } & \multicolumn{2}{|c|}{ Days after transplanting } \\
\cline { 2 - 3 } & 30 DAT & At Harvesting \\
\hline $\mathbf{T}_{\mathbf{1}}$ & 0.43 & 0.35 \\
\hline $\mathbf{T}_{\mathbf{2}}$ & 0.52 & 0.43 \\
\hline $\mathbf{T}_{\mathbf{3}}$ & 0.57 & 0.49 \\
\hline $\mathbf{T}_{\mathbf{4}}$ & 0.49 & 0.40 \\
\hline $\mathbf{T}_{\mathbf{5}}$ & 0.55 & 0.46 \\
\hline $\mathbf{T}_{\mathbf{6}}$ & 0.61 & 0.53 \\
\hline $\mathbf{T}_{\mathbf{7}}$ & 0.54 & 0.45 \\
\hline $\mathbf{S E m} \pm$ & $\mathbf{0 . 0 0 4 5}$ & $\mathbf{0 . 0 0 5 5}$ \\
\hline $\mathbf{C D}(\mathbf{5 \%})$ & $\mathbf{0 . 0 1 3 5}$ & $\mathbf{0 . 0 1 6 4}$ \\
\hline
\end{tabular}


Table.3 Effect of phosphorus, FYM and VAM on available nitrogen under rice crop

\begin{tabular}{|c|c|c|c|}
\hline \multirow[t]{2}{*}{ Treatment } & \multicolumn{3}{|c|}{ Days After Transplanting ( DAT ) } \\
\hline & 30 DAT & 60 DAT & At Harvesting \\
\hline $\mathbf{T}_{1}$ & 214 & 194 & 183 \\
\hline $\mathbf{T}_{2}$ & 246.35 & 223.35 & 110.35 \\
\hline $\mathbf{T}_{3}$ & 266.30 & 242.30 & 226.40 \\
\hline $\mathbf{T}_{4}$ & 228.00 & 206 & 191.60 \\
\hline $\mathbf{T}_{5}$ & 258.00 & 240.40 & 228.60 \\
\hline $\mathbf{T}_{6}$ & 280.40 & 262.50 & 248.46 \\
\hline $\mathbf{T}_{7}$ & 256.45 & 236.45 & 223.60 \\
\hline SEm \pm & 0.5528 & 0.5118 & 0.6486 \\
\hline CD $(5 \%)$ & 1.6454 & 1.5205 & 1.9270 \\
\hline
\end{tabular}

Table.4 Effect of phosphorus, FYM and VAM on available phosphorus under rice crop

\begin{tabular}{|c|c|c|c|}
\hline \multirow{2}{*}{ Treatment } & \multicolumn{2}{|c|}{ Days After Transplanting } & \multicolumn{1}{c|}{ DAT $)$} \\
\cline { 2 - 4 } & 30 DAT & 60 DAT & At Harvesting \\
\hline $\mathbf{T}_{\mathbf{1}}$ & 11.3 & 9.4 & 6.5 \\
\hline $\mathbf{T}_{\mathbf{2}}$ & 19.4 & 17.8 & 16.4 \\
\hline $\mathbf{T}_{\mathbf{3}}$ & 27.5 & 24.5 & 22 \\
\hline $\mathbf{T}_{\mathbf{4}}$ & 15.8 & 13.2 & 11.8 \\
\hline $\mathbf{T}_{\mathbf{5}}$ & 24.3 & 20.9 & 18.9 \\
\hline $\mathbf{T}_{\mathbf{6}}$ & 16.4 & 14.8 & 12 \\
\hline $\mathbf{T}_{\mathbf{7}}$ & 23.5 & 20 & 18.6 \\
\hline $\mathbf{S E m} \pm$ & $\mathbf{0 . 8 1 1 6}$ & $\mathbf{0 . 9 7 5 9}$ & $\mathbf{0 . 3 9 8 4}$ \\
\hline $\mathbf{C D}(\mathbf{5 \%})$ & $\mathbf{2 . 4 1 1 5}$ & $\mathbf{2 . 8 9 9 5}$ & $\mathbf{1 . 1 8 3 7}$ \\
\hline
\end{tabular}

Table.5 Effect of phosphorus, FYM and VAM on available potassium under rice crop

\begin{tabular}{|c|c|c|c|}
\hline \multirow{2}{*}{ Treatment } & \multicolumn{2}{|c|}{ Days After Transplanting } & \multicolumn{1}{c|}{ (DAT ) } \\
\cline { 2 - 4 } & 30 DAT & 60 DAT & At Harvesting \\
\hline $\mathbf{T}_{\mathbf{1}}$ & 225 & 209 & 188 \\
\hline $\mathbf{T}_{\mathbf{2}}$ & 239 & 223 & 200 \\
\hline $\mathbf{T}_{\mathbf{3}}$ & 250 & 236 & 207 \\
\hline $\mathbf{T}_{\mathbf{4}}$ & 235 & 221 & 199 \\
\hline $\mathbf{T}_{\mathbf{5}}$ & 243 & 230 & 209 \\
\hline $\mathbf{T}_{\mathbf{6}}$ & 255 & 242 & 220 \\
\hline $\mathbf{T}_{\mathbf{7}}$ & 241 & 229 & 204 \\
\hline $\mathbf{S E m} \pm$ & $\mathbf{2 . 2 9 3 0}$ & $\mathbf{3 . 1 4 9 7}$ & $\mathbf{3 . 2 1 2 1}$ \\
\hline $\mathbf{C D}(\mathbf{5 \%})$ & $\mathbf{6 . 8 1 2 9}$ & $\mathbf{9 . 3 5 8 3}$ & $\mathbf{9 . 5 4 3 6}$ \\
\hline & & & \\
\hline
\end{tabular}


Fig.1 Effect of integrated use of phosphorus, FYM and VAM on pH under rice crop

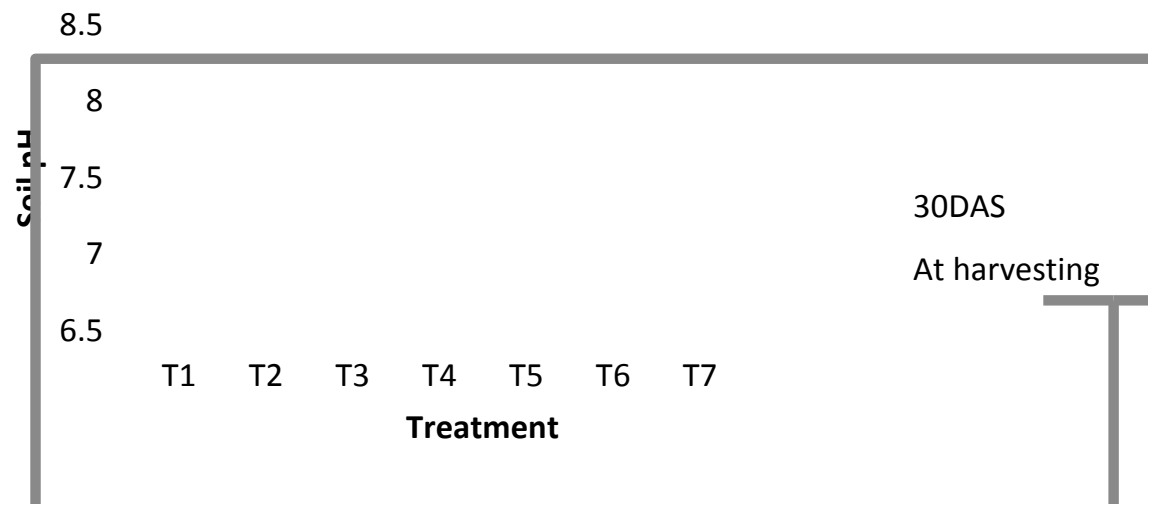

Fig.2 Effect of integrated use of phosphorus, FYM and VAM on Electrical conductivity under rice crop

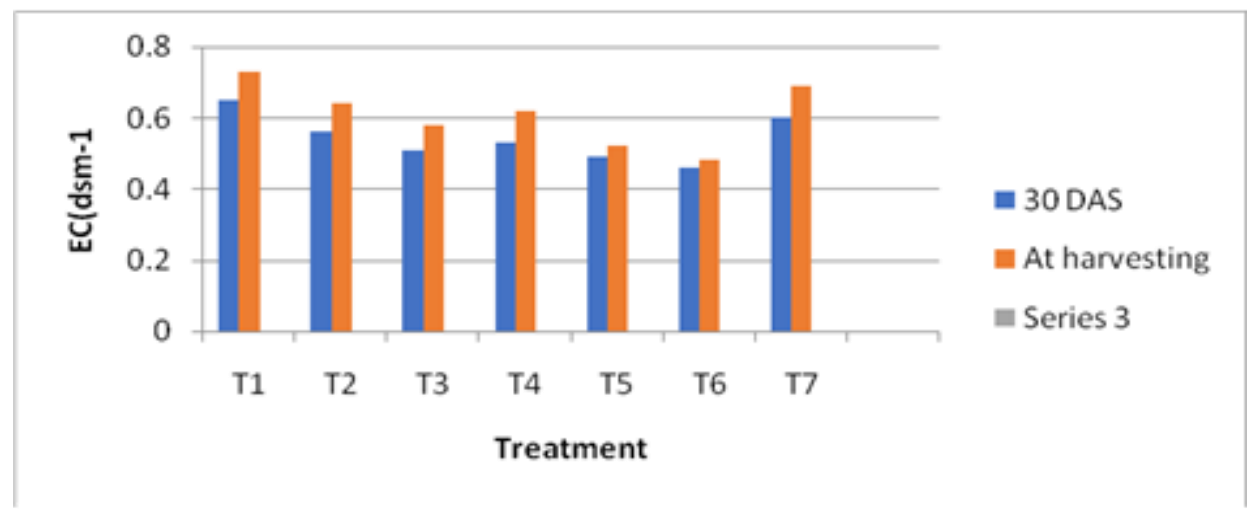

Fig.3 Effect of integrated use of phosphorus, FYM and VAM on dry matter ( $\mathrm{g} \mathrm{m}^{-1}$ row length), grain and straw yield $\left(\mathrm{q} \mathrm{ha}{ }^{-1}\right)$ of rice crop

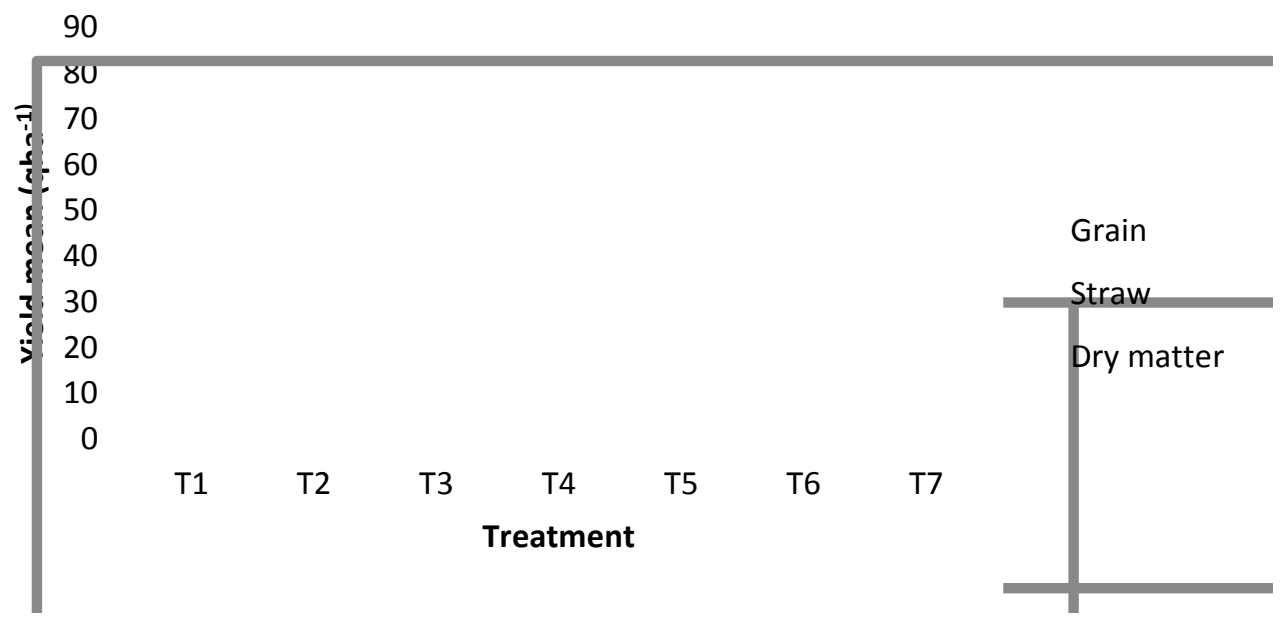




\section{Available nitrogen}

Available nitrogen content of soil under rice have presented in table-3. The data revealed that available nitrogen content of soil decreased continuously with advancement in crop growth stage under all treatments. Statistically was significant difference was observed among between $T_{7}$ and $T_{5}$ at 30 DAT. The plots treated with $30 \mathrm{~kg} \mathrm{P}$ ha ${ }^{1}+\mathrm{VAM}+\mathrm{FYM} @ 10 \mathrm{ta} \mathrm{ha}^{-1}\left(\mathrm{~T}_{6}\right)$ recorded significantly higher available nitrogen content as compared to other treatments. Decline in nitrogen content with increase in age of crop can be attributed to $\mathrm{N}$ requirement for the crop with age. The favourable soil conditions under organic manure application might have facilitated the mineralization of soil $\mathrm{N}$ leading to build up of higher available nitrogen (Vipin Kumar and Singh 2010).

\section{Available phosphorus}

Data showed that available phosphorus content of rice plots decreased continuously with age of crop under all treatments (table 4). The effect of various treatment of phosphorus fertilizer, VAM and FYM on available phosphorus content of soil was recorded significantly. Higher in the treatment $\mathrm{T}_{3}$ ie $60 \mathrm{~kg} \mathrm{P} \mathrm{ha}^{-1}+\mathrm{VAM}$. In case of available phosphorus statistically significance difference was observed among the treatments except between $T_{7}, T_{5}$ and $T_{6}, T_{4}$ which was remained at par 30 DAT and at harvesting. Increase in available phosphorus content of soil due to increasing level of phosphorus might be attributed to direct addition of phosphorus to solution pool of phosphorus in soil. The increase in available phosphorus content of soil due to the incorporation FYM and VAM might be attributed solubilisation of native phosphorus through release of various organic acids during the decomposition of FYM. The increase in available $\mathrm{P}$ content of soil due to the incorporation of FYM may be attributed to the direct addition of $\mathrm{P}$ as well as solubilisation of native $\mathrm{P}$ through release of various organic acids during decomposition. A part of that VAM helped to enhance the mobility of P. Similar result was observed by Sharma et al., (2005) and Shinde and Bangar, 2003).

\section{Available potassium}

Available potassium content of soil decreased continuously with advancement in crop growth stage under all treatments. Significantly higher soil available potassium content was observed in the treatment $\mathrm{T}_{6} 30$ kg P ha ${ }^{-1}+\mathrm{VAM}+\mathrm{FYM} @ 10 \mathrm{ta} \mathrm{ha}^{-1}$.In case of available potassium statistically significance difference was observed among the treatments except between $T_{7}$ and $T_{5}$ which was remained at par 30 DAT and at harvesting. Increase in available $\mathrm{K}$ due to phosphorus, VAM and FYM application might be attributed to the addition of potassium from decomposition of FYM to the available pool of soil. A part of that the beneficial effect of FYM on available $\mathrm{K}$ might be attributed to the reduction in fixation and release of $\mathrm{K}$ due to interaction of FYM with clay. Similar reports were also observed by Laxminarayana (2005). These observation by Abraham Lal (2004) and Thakur et al (2011).

Effect of phosphorus, FYM and VAM on dry matter, straw and grain yield of rice

\section{Dry matter}

The data revealed that the dry matter yield of rice was found in the order $T_{6}>T_{3}>T_{5}>T_{7}>$ $\mathrm{T}_{2}>\mathrm{T}_{4}>\mathrm{T}_{1}$ and the values of grain yield were $82.24,75.24,64,62,57.24,55.72,42.42$ $\mathrm{gm} / \mathrm{m}$ under respective treatments. In case of dry matter yield statistically significance difference was observed among the treatment except between $\mathrm{T}_{7} \mathrm{~T} 5$ which was remained at 
par at harvesting. Application $30 \mathrm{~kg} \mathrm{P} \mathrm{ha}^{-1}+$ VAM + FYM 10 ta ha ${ }^{-1}$ i.e $\left(\mathrm{T}_{6}\right)$ recorded significant higher yield in comparison to other treatments. It might be due to more availability of nutrients under $\mathrm{P}+\mathrm{VAM}+$ FYM application led by the vegetative growth of crop.

\section{Grain yield}

The effect of integrated use of phosphorus, VAM and FYM on grain ( $\mathrm{q} \mathrm{ha}^{-1}$ ) yield of rice have presented in figure -2 The data revealed that the grain yield of rice was found in the order $T_{6}>T_{3}>T_{5}>T_{7}>T_{2}>T_{4}>T_{1}$ and the values of grain yield were $48,45.44,43.42$, $42,38.25,34.46$ and $30.42 \mathrm{q} \mathrm{ha}$ under respective treatments. In case of grain yield statistically significance difference was observed among the treatment except between $\mathrm{T}_{7}$ and $\mathrm{T} 5$ which was remained at par at harvesting. Application $30 \mathrm{~kg} \mathrm{P}^{-1}+\mathrm{VAM}$ + FYM 10 ta ha $^{-1}$ i.e $\left(\mathrm{T}_{6}\right)$ recorded significant higher yield in comparison to other treatments. It might be due to more availability of nutrients under P+ VAM + FYM application led by the vegetative growth of crop.

\section{Straw yield}

The data revealed that the straw yield of rice was found in the order $T_{6}>T_{3}>T_{5}>T_{7}>T_{2}>$ $\mathrm{T}_{4}>\mathrm{T}_{1}$ and the values of straw yield were $68.54,60.42,55.64,54,47.45,44.46,40.42$ q $\mathrm{ha}^{-1+}$ under respective treatments. In case of straw yield statistically significance difference was observed among the treatment except between $\mathrm{T}_{7} \mathrm{~T} 5$ which was remained at par at harvesting. Application $30 \mathrm{~kg} \mathrm{P} \mathrm{ha}^{-1}+$ $\mathrm{VAM}+\mathrm{FYM} 10$ ta $\mathrm{ha}^{-1}$ i.e $\left(\mathrm{T}_{6}\right)$ recorded significant higher yield in comparison to other treatments. It might be due to more availability of nutrients under P + VAM + FYM application led by the vegetative growth of crop.

\section{Acknowledgement}

I am very acknowledge to the department of Agricultural chemistry and Soil Science in Udai Pratap Autonomous College, Varanasi (U.P.), I am also thankful to my guide and friends to support me for availing the laboratory facilities.

\section{References}

Arezoo, k., Akbari, N. and Chaichi , R.M.2008. Limited Irrigation and Phosphorus fertilizer effects on yield and yield components of grain sorghum. American Eurasian Journal of Agriculture and Environmental Science, 3(5); 697-702.

Bajpai, R. K., Chita, t. S., Upadhayay, S. K. and Urkukar, J. S.2006 Long term Studies on soil physico-chemical properties and productivity of rice-wheat system management in inceptisol of Chhattisgarh. Journal of the Indian Society of Soil Science. 54(1)24-29.

Black, C.A., 1971.Mehtod of soil analysis, part 2 Medison Wisconsin U.S.A . American Society of agronomy.

Chesnin, L., and Yien, C.H.1951. Trubidimetric determination of available sulphate in soil. Soil Science Society of American Proceeding.

Datta, S.K., Sarka, M. A. R and Uddin, F.M.J.2013. Effect of variety and level of phosphorus on the yield components of lentil. International Journal of Agricultural Research Innovation and Tech. 3(1)78-82.

Hernandez, M, Cuevas F. 2003The effect of inoculation with aerbuscular mycorriza and Bradyrhizobium strains on soybean (Glycine max L.) crop development. Cultivation- Tropicals. 24(2):19-21.

Jackson, M.L.1967. Soil Chemical Analysis Practice Hall of Indian (P) Ltd, New Delhi. 
Jackson, M.L.1973.Soil Chemical Analysis Practice Hall of India (P) Ltd, New Delhi.

Kumar/ Vipin and Prasad, R.K.2008.Integrated effect of mineral fertilizer and green manure on crop yield and nutrient availability under rice wheat cropping system in calciorthents. Journal of Indian Society of Soil Science, 56(2) 209-214

Kaleem, S., Ansar, M., Ali, M.A., Sher, A. 2009. Effect of phosphorus on the yield abd yirld components of wheat variety under rainfed conditions. Sarhed Journal of Agricultura Rrearch, 25(1).

Laxminarayana, K.,2005. Effect of $P$ solubilising microorganisms on yield of rice and nutrient availability in an acid soil Mizoram. Journal of the Indian Socity of Soil Science 53, (2)240-243.

Lakkra, A., Singh, D., Prasad, V. Deepanshu and Shahi,M.2017.Effect of Nitrogen and phosphorus on growth and yield of radish Pusha chetki under shade net condition. The Pharma Innovation Journal, 6(11):768-770.

Masood, T., Gulr, R, Munsif, F.; Jalal, F.; Hussain, Z.; Noreen, N.; Khan, $\mathrm{H}$ and Khan, H.2011. Effect of different phosphorus levels on the yield and yield components of maize. Sarhad Journal.Agricultural, 27(2).

Meena, P.O., Meena, K.R., Dhaka, S, R and Sharma, A.2017. Effect of nitrogen and phosphorus levels on growth and yield of bottle ground. International Journal of Pure and Applied Bioscience. 5(4):1178-1184.

Mondal, G. K., Pal, S. K . and Roy,A.2007.phosphorus availability indices of soils under various Land uses in Tarai zone of West Bengal. Journal of the Indian Society of Soil Science.55, 36-39.

Olsen, S, r., Cale, C.V., Watanble, F.S. and Dean, L.A.1954. Estimation of
Available Phosphorus in soil by extraction sodium bicarbonate.Cire.U.S.Deptt.Agri, 939.

Pandey, S.P., Kundpal, B.K., Kumar, S., Rathore, S.S., Sekhawat, Kapila and Bhogal, N.S.2012. Availability of phosphorus and sulpur in Inceptisols of central Uttar Pradesh. Journal of the Indian Society of Soil Science.48, 118121.

Bhogal, N. S. 2012. Phosphorus use efficiency of Indian mustard under semi arid conditions in relation to phosphorus solubilising and mobilizing micro organisms and $\mathrm{P}$ fertilization. National Academy Science Letters.35, 547-553.

Rodiriguezs, D, Andrade F.H. and Goudiraan, J. 2002 Effects of phosphorus Nutrition on tiller emergence in wheat. Amarican Journal of Plant and Soil, (2):283 -295.

Sharma, S; Duber, Y.P., Kaistha B.P., and Verma, T.S.2005. Effect of Rhizobium inoculation and phosphorus level on symbiotic parameter, growth and yield of French bean (phaseolus vulgaris L.) in North western acid Alfisol. Legume Research, (28)103-106.

Sharma, P.K. and Gupta, J.P.1994. Phosphorus utilization and root Cation Exchange capacity in wheat as by phosphorus, Lime and FYM on Alfisol of western Himalayan region. Journal of the Indian Society of Soil Science.42, 65-68

Sharma, P. K. and Raina, A. 1994 Effect of the phosphorus on the bulb yield and $\mathrm{P}$ used efficiency as influenced by FYM in onion crop in acid soil from western Himalayas. Journal of Indian Society of Soil Science 42, 68 - 72.

Sharma, H.R., Manchanda and Kapoor, A.K. 2007. Phosphorus requirement of wheat under chloride and sulphate dominated salinities. Journal of the Indian Society of Soil Science, (4)509-514.

Shinde, J. P., Singh, D.S., Mehela and 
Bhardwaj, K.K 2005. Effect of integrated Use of inorganic fertilizer and organic materials on the distribution of different form of nitrogen and phosphorus in soil. Journal of the Indian Society of Soil Science, (1) 80 - 84.

Singh, B., and Bishnoi, S.R. 1993. Determination of critical Levels of available Soil phosphorus for maize. Journal of the Indian Society of Soil Science.41, 501-503.

Singh, M.v.2007.Problems of micro and secondary in acid soils of Indian and their manage me bulletin of. Indian Society of Soil Science. 25, 27-58.

Singh, Y.G.R., Najar, Singh Ummed and Singh, J.K.2010. Phosphorus Management in maize- onion cropping sequence under rained temperate conditions of inceptiosol. Journal of the Indian Socity of Soil Science, (4)355361.

\section{How to cite this article:}

Abhishek Kumar Shukla, Sanjay Shahi, Niteesh Patel and Sandeep Patel. 2020. Effect of Phosphorus, VAM and FYM on Soil Fertility Status under Rice Cultivation. Int.J.Curr.Microbiol.App.Sci. 9(07): 3766-3775. doi: https://doi.org/10.20546/ijcmas.2020.907.441 